Aletria, Belo Horizonte, v. 29, n. 3, p. 169-188, 2019

(c) (i)

\title{
Discussões teórico-críticas sobre representação das margens em contos latino-americanos contemporâneos
}

\section{Theoretical-Critical Discussions about Representation of the Margins in Contemporary Latin American Short Stories}

\author{
Alessandra Maia de Lemos \\ Universidade do Estado do Rio de Janeiro (UERJ), Rio de Janeiro, Rio de Janeiro / Brasil \\ alessandra.lemos83@gmail.com
}

Resumo: A maneira como um grupo marginal é representado na literatura revela a visão que se tem dele. Em tempos em que se acirram a intolerância e o preconceito a minorias sociais, a literatura latino-americana contemporânea se reafirma como denúncia social, propondo um olhar mais sensível e altruísta sobre estes grupos. Assim, é fundamental que a construção narrativa sobre o outro suscite empatia e não desprezo. Nesse sentido, a crítica e a teoria literárias no tempo presente, no que se refere à representatividade de indivíduos à margem, observarão como uma narrativa reforça ou desconstrói estereótipos. Este artigo apresenta algumas dessas teorias e críticas mais recentes como o choque do real, o novo realismo e o belo de Flusser - e, a partir delas, analisa quatro contos latino-americanos contemporâneos: "La zona", de Laura Santullo; "El carrito", de Mariana Enriquez; "Fábrica de fazer vilão", de Ferréz; e "Vestido Longo", de Marcelino Freire.

Palavras-chave: literatura latino-americana; representação marginal; novo realismo; choque do real; belo.

Abstract: The way in which a marginal group is represented in literature reveals how it is seen. In times of intolerance and prejudice against social minorities, contemporary Latin American literature reaffirms itself as a social complaint, proposing a more sensitive and altruistic view of these groups. Thus, it is fundamental for the narrative construction about the other to raise empathy instead of contempt. Therefore, criticism and literary theory in the present time, regarding the representation of individuals at

DOI: $10.17851 / 2317-2096.29 .3 .169-188$ 
the margin of society, observe how a narrative reinforces or deconstructs stereotypes. This article presents some of these more recent theories and criticisms - such as the shock of the real, new realism and Flusser's beauty criticism - and, thereafter, analyzes four contemporary Latin American short stories: "La zona", by Laura Santullo, "El carrito", by Mariana Enriquez, "Fábrica de fazer vilão", by Ferréz; and "Vestido longo", by Marcelino Freire.

Keywords: contemporary Latin American literature; marginal representation; new realism; shock of the real; beauty.

Segundo o mestre Antonio Candido, a literatura desenvolve em nós a cota de humanização de que precisamos enquanto indivíduos. Essa humanização inclui estar aberto ao outro e compreendê-lo. ${ }^{1} \mathrm{~A}$ representação desse outro nas artes, portanto, é fundamental para conhecê-lo, principalmente quando este foi, por muito tempo, silenciado ou supostamente caricaturalmente representado ao longo da historiografia literária, como é o caso de grupos socialmente marginalizados. Que imagem sobre negros, pobres, prostitutas, homossexuais e mulheres foi construída historicamente nos textos literários? O que se costumou ler em narrativas que envolvem personagens que representam estes grupos? Que ações, posturas e experiências estão relacionadas a esses indivíduos na literatura?

O filósofo tcheco-brasileiro Vilém Flusser defende que essa emancipação do ser humano possa se dar por meio da experiência estética com o objeto artístico - no caso aqui estudado, com a literatura - e faz uma diferenciação dessa experiência a partir do hábito. Quando estamos habituados a uma informação, a uma situação, significa que não experimentamos nada de novo. Nesse sentido, Flusser discute sobre a necessidade da arte, dizendo que esta é a nossa maneira de viver no real, pois “'onde não há modelo estético, nós estamos 'anestesiados' = nós não temos experiência nenhuma. Nós dependemos da arte para poder perceber o mundo" $2 \mathrm{e}$ - acrescento - o semelhante. Ao produzir o real, a arte comunica, e comunica por meio de uma experiência estética que se aproxime de uma experiência concreta. A arte é, pois, um meio de conhecer e entender realidades. Os modelos de experiência propostos

${ }^{1}$ CANDIDO. Vários escritos, p. 182.

${ }^{2}$ FLUSSER. A arte: o belo e o agradável, p. 10. 
pelos objetos artísticos podem, segundo Flusser, circular em algumas zonas dependendo do grau de informação que proporcionar.

Para Flusser, comunicação e informação são inversamente proporcionais: quanto mais se informa, menos se comunica; quanto mais se comunica, menos se informa. À medida que uma fala é redundante, ela não agrega nenhuma informação nova; ao passo que se uma fala não é óbvia, apresenta mais informação. ${ }^{3}$ A partir dessa teoria, Flusser apresenta as zonas de ciclo estético que vão do feio ao agradável. Nessa escala, o feio, no qual começa o ciclo, se refere a toda nova criação - que é detestável e feio porque se contrapõe a tudo a que se está acostumado-e o agradável é a zona de conforto, de experiência nula, que não acrescenta informação alguma. Nesse processo, surge o belo:

O novo é um ruído. Ele me perturba, é repugnante. Odeio-o. A criatividade começa com o feio. [...] Aos poucos os elementos perturbadores são integrados. Eles criam espaço para si na memória e começam a irradiar de modo peculiar. $\mathrm{O}$ novo se torna informativo. Ele dá sentido à memória em sua totalidade. Essa é uma definição de belo. ${ }^{4}$

O belo, portanto, significa informação nova para uma experiência do real. A beleza é terrível, segundo Flusser, porque, à medida que apresenta uma nova informação, propõe uma modificação das nossas experiências com o real. ${ }^{5}$

Nesse contexto, como a literatura no tempo presente produzirá informação nova que provoque a observação crítica do espectador? Um dos caminhos para alcançar essa proposta é provocar o choque do real como experiência estética narrativa.

O termo "choque do real" foi apresentado por Beatriz Jaguaribe (2007) para nomear a utilização de estéticas realistas que visam ao efeito catártico, buscando provocar o incômodo e a sensibilização no espectador, sem cair no sensacionalismo, além de chamar atenção para a denúncia social.

Ao falar dessa estética do real, Jaguaribe parte especificamente das produções brasileiras que têm os grandes centros metropolitanos

\footnotetext{
${ }^{3}$ FLUSSER. Comunicologia: Reflexões sobre o futuro, p. 197.

${ }^{4}$ FLUSSER. Comunicologia: Reflexões sobre o futuro, p. 196.

${ }^{5}$ FLUSSER. A arte: o belo e o agradável, p. 12.
} 
como espaços de contradições entre uma democracia e as desigualdades socioeconômicas que culminam na exclusão social. Nesse contexto, surge uma cultura do medo construída pela intensificação da ideia de risco e de violência. A partir daí, a professora chama atenção para a ocorrência de uma saturação de imagens e de narrativas midiáticas que "espetacularizam" a realidade contemporânea, expondo uma realidade de forma a provocar medo e horror em vez de uma reflexão objetiva e de um pensamento crítico sobre ela. ${ }^{6}$ Diante desse cenário, Jaguaribe discute sobre a produção de retratos de fatos contundentes da realidade, que não se apresentem como "mais do mesmo", mas que funcionem como uma pedagogia do real, ${ }^{7}$ construam significados que se diferenciem dos produtos da mídia televisiva e retratem uma realidade que potencialize narrativas significativas. Promovendo, dessa forma, uma experiência do real.

Jaguaribe identifica essa estética do novo realismo tanto no cinema quanto na literatura. Aponta, como uma das características, o olhar próximo dessas vivências ou de dentro delas. De maneira diversa dos romances realistas do século XIX, em que o olhar do narrador está distanciado da realidade narrada - e, portanto, também distancia o leitor dela - os textos realistas contemporâneos buscam uma legitimidade na construção narrativa, seja porque o narrador viveu a realidade narrada, seja porque a testemunhou. ${ }^{8}$ Em outras palavras, a principal mudança entre o realismo do século XIX e o novo realismo contemporâneo é o ponto de vista, conforme também destaca Karl Erik Schollhammer. ${ }^{9}$ Nesse sentido, o lugar de fala torna-se fator fundamental para aproximar o leitor da vivência narrada.

Uma das estratégias narrativas para determinar esse lugar de fala é o uso da primeira pessoa. Antonio Candido, discutindo sobre a literatura de 1960 e 1970 em seu ensaio "A nova narrativa", afirma que o estabelecimento deste realismo feroz se faz melhor na primeira pessoa, uma vez que "a brutalidade da situação é transmitida pela brutalidade do seu agente (personagem), ao qual se identifica a voz narrativa, que assim descarta qualquer interrupção ou contraste crítico entre narrador e

\footnotetext{
${ }^{6}$ JAGUARIBE. O choque do real: estética, mídia e cultura, p. 98-99.

${ }^{7}$ JAGUARIBE. O choque do real: estética, mídia e cultura, p. 99.

${ }^{8}$ JAGUARIBE. O choque do real: estética, mídia e cultura, p. 108-109.

${ }^{9}$ SCHOLLHAMMER. Ficção brasileira contemporânea, p. 53.
} 
matéria narrada". ${ }^{10}$ Tal estratégia e seus efeitos podem ser identificados em muitos contos latino-americanos contemporâneos, dentre eles, os estudados no presente artigo.

Candido reforça o distanciamento crítico da narrativa em terceira pessoa do antigo realismo, chamando atenção para a ausência da desejada identificação com a realidade narrada. Tal identificação não ocorre porque o narrador distanciado se utilizará de estratégias linguísticas e narrativas - tais como a reprodução de temas e situações daquela realidade e modos de falar dos habitantes - que, na tentativa de retratar este universo e o indivíduo que nele vive, acaba por excluí-los, na medida em que incorre na folclorização e reforça estereótipos, características que para o leitor de classe média têm o mesmo atrativo que qualquer outro pitoresco. ${ }^{11}$

Corroborando esta discussão, Tânia Pellegrini alerta para o perigo desta estereotipagem que, unida a uma "espetacularização" da violência que ignora o contexto histórico e social da realidade narrada, retrata o pobre, o feio, o negro, a prostituta e demais minorias como risco e ameaça para a sociedade. ${ }^{12}$ Pellegrini acrescenta, ainda, que o rompimento desses estereótipos se dá pela não estetização da miséria, por uma narrativa que, embora violenta e traumática, apresente os indivíduos de maneira a enxergarmo-los como seres humanos, e não como animalizados, ignorantes, ameaçadores, cruéis e violentos. ${ }^{13}$ Imagem que, segundo Regina Dalcastagné, não representa o outro, mas o modo como o querem ver. ${ }^{14}$

A utilização da primeira pessoa, aliada a estratégias narrativas que subvertem o senso comum e desconstroem estereótipos e à utilização de uma linguagem mais objetiva, é o que faz de contos como "La zona", de Laura Santullo, efetivamente proporem a experiência de uma realidade bruta e apresentarem o indivíduo que nela vive.

No conto mencionado, a escritora uruguaia escolhe um narrador-personagem para nos contar a história de uma cidade privada e autossuficiente, delimitada por muros que separam a classe média

\footnotetext{
${ }^{10}$ CANDIDO. A nova narrativa, p. 212-213.

${ }^{11}$ CANDIDO. A nova narrativa.

${ }^{12}$ PELLEGRINI. No fio da navalha: literatura e violência no Brasil de hoje, p. 49.

${ }^{13}$ PELLEGRINI. No fio da navalha: literatura e violência no Brasil de hoje, p. 51-52.

${ }^{14}$ DALCASTAGNÈ. Vozes nas sombras: representação e legitimidade na narrativa contemporânea, p. 88.
} 
dos pobres, conhecida como La Zona. Aterrorizados pela violência "provocada pelos pobres e marginais" e descrentes da eficiência das autoridades, pais de famílias, "dotados de um alto senso de justiça", ergueram muros isolando-se, com suas escolas, seus hospitais, sua segurança, seus comércios e seus lazeres. E assim vivem em paz, maridos com suas esposas e seus filhos. O narrador, ex-morador de La Zona, dá início à narrativa revelando a base desta cidade: "Esses muros estão cheios de ódio, foram construídos com tijolos e cimento de cal e medo". ${ }^{15}$ Os mesmos medos e ódios que levaram à criação destas cidades autônomas de classe média são os que estão na cultura do medo e do terror, provocada pela violência exacerbada e estereotipada pela mídia e pelas produções sensacionalistas. Contrapondo-se a La Zona, a que o narrador se refere como "reino limpo ou higienizado", estavam as "cidades da miséria", que cresciam sem proteção, restrição ou estrutura e eram formadas por "construções miseráveis, duplamente menores sob meu ponto de vista". ${ }^{16}$

A situação inicial narrada no conto é a invasão, seguida de roubo e morte, a uma das mansões de La Zona. Uma idosa, dona da mansão, falece, e dois dos três assaltantes morrem; o terceiro foge. A partir daí, todos os cidadãos de La Zona se reúnem para traçar estratégias a fim de encontrar o terceiro agente da ofensa, pois este representa um risco à cidade. Em uma destas reuniões, o narrador-personagem nos conta os planos para encontrar o rapaz e fazê-lo pagar pelo que fez:

Os mais moderados propunham subornar quem fosse necessário a fim de mudar o local dos acontecimentos para outro lugar longe de La Zona, havia quem garantisse dispor de favores de representantes políticos da mais alta hierarquia, os quais poderiam colocar uma pedra sobre o assunto sem derramar mais sangue. Outros vociferavam que não havia espaço para a compaixão, que haviam estrangulado a velha impiedosamente, que eles eram escória, que o lixo tinha que ser eliminado. Os outros cadáveres já haviam desaparecido convenientemente [...]. Aquele sobrevivente era o único obstáculo perigoso, era o inimigo. Sobre a possibilidade de uma execução, só se

15 "[...] esos muros están llenos de odio, los fabricaron con ladrillos y con argamasa de cal y miedo." (SANTULLO. La zona, p. 54, tradução minha).

16 " [...] construcciones miserables doblemente empequeñecidas desde mi punto de vista." (SANTULLO. La zona, p. 56, tradução minha). 
falava evasivamente. No fundo ainda havia a ideia de que, no momento de sua captura, o indivíduo, que certamente estaria armado, iria resistir com a violência, o que, sem dúvida, tornaria as coisas moralmente mais fáceis. ${ }^{17}$

Após apresentar o pai e compará-lo a outros moradores como pessoas dotadas de "alto senso de justiça", o narrador nos mostra o lado imoral das "pessoas de bem". Além disso, a escolha das palavras para se referir ao assaltante revelam a pesada visão que a classe média tem sobre o outro marginalizado: escória, lixo, inimigo.

$\mathrm{O}$ assaltante, um jovem em torno dos quinze anos, se esconde no sótão da casa do narrador. Este o encontra e, embora a primeira reação tenha sido conflituosa fisicamente, o percebe frágil, fraco, o que o remete a uma frase recorrente do pai: "do outro lado comem mal, por isso crescem menos". ${ }^{18}$ É pelo ponto de vista do narrador-personagem - um jovem de classe média - que conhecemos o rapaz envolvido no assalto. A escolha do ponto de vista narrativo é estratégia que busca permitir a aderência do olhar do leitor àquele sujeito de condições mais ou menos conhecidas. O rapaz-narrador não denuncia o rapaz-miserável: atônito, não sabe o que fazer com esta informação. Passa a visitá-lo todos os dias até decidir o que fazer. Na medida em que o próprio narrador se aproxima afetivamente do assaltante, vendo-o como humano, nós o seguimos no mesmo caminho: o da empatia.

O pai do narrador descobre o esconderijo do ofensor e o leva à vizinhança para decidirem, democraticamente, o que fazer com o rapaz. Então, o narrador nos mostra uma cena violenta: uma experiência de

17 "Los moderados proponían sobornar a quien fuera necesario para cambiar el lugar de los hechos a otro sitio lejos de La zona, había quien aseguraba disponer de los favores de encumbrados representantes de la escena política que podían poner piedras sobre el asunto sin derramar más sangre. Otros vociferaban que no había sitio para la compasión, habían estrangulado a la anciana sin piedad, eran escoria, se debía acabar con la basura. Los otros cadáveres ya habían desaparecido convenientemente [...]. Aquel sobreviviente era el único escollo peligroso, era el enemigo. De la posibilidad de una ejecución se hablaba sólo con evasivas. En el fondo subsistía la idea de que a la hora de su captura, el individuo, quien seguramente estaría armado, iba a resistirse con violencia, lo que sin duda facilitaría moralmente las cosas." (SANTULLO. La zona, p. 58, tradução minha).

18 "[...] del otro lado comen mal, por eso crecen menos." (SANTULLO. La zona, p. 60, tradução minha). 


\section{choque do real cuja carga tem como agente os cidadãos de La Zona e, como vítima, o rapaz envolvido no assalto:}

os vizinhos inflamados se aglomeravam vociferando, alguém muito próximo acertou o primeiro golpe no rosto do ladrão. [...] Em um instante a situação saiu de controle... a represa estava quebrada, nada conseguia parar o fluxo de raiva e tensão que se acumularam nos últimos dias. Vi os rostos de meus vizinhos cegados pela raiva, mãos cerradas, rostos avermelhados e transformados pelo ressentimento. [...] Eu nunca voltei a ver um gesto de terror tão intenso quanto o de seu rosto quando se viu engolido por aquela turba cheia de ódio. Seus olhos aterrorizados pediam ajuda, pediam misericórdia, pediam perdão, enquanto ele erguia as mãos desajeitadamente em uma tentativa vã de proteger a cabeça. [...] Em um instante a massa humana o engoliu entre empurrões e gritos e chutes. Ele desapareceu entre as pessoas. Então veio uma pausa, um silêncio ensurdecedor. Como se aqueles homens e mulheres tivessem finalmente recuperado sua sanidade, começaram a ceder e a afastar-se até que deixaram um vazio no centro. [...] Com um murmúrio abafado, a massa foi recuperando sua aparência humana, dispersando-se em pequenos grupos, começaram a se mover em direção a seus lares. Algumas mulheres que demoraram a sair escondiam os olhos ou faziam o sinal da cruz diante do cadáver, a maioria acelerou o passo, fugindo do pavor daquele corpo sem vida, como se aquela execução pública tivesse sido nada mais que um terrivel acontecimento do qual não fizeram parte. ${ }^{19}$

19 ، “...] los vecinos enardecidos se agolparon alrededor vociferando, alguien que estaba muy cerca amagó el primer golpe a la cara del ladrón. [...] En un instante la situación se salió de control... la represa estaba rota, ya nada podía detener el caudal de rabia y tensión que se había acumulado en los últimos días. Vi las caras de mis vecinos enceguecidos por la ira, las manos crispadas, los rostros enrojecidos y transformados por el resentimiento. [...] Nunca he vuelto a ver un gesto de terror tan intenso como el de su rostro cuando se vio tragado por aquella turba llena de odio. Sus ojos aterrados pedían auxilio, pedían clemencia, pedían perdón, mientras alzaba las manos torpemente en un intento vano por protegerse la cabeza. [...] En un instante la masa humana lo engulló entre empujones y gritos y patadas. Desapareció entre la gente. Después vino 
Subvertendo os papéis de ofensor e ofendido, de agressor e de vítima, o narrador nos mostra uma classe média, tradicionalmente vista como civilizada e esclarecida, agora desumanizada. Agindo sob uma alienação provocada pela cultura do terror e do ódio, como se suas ações não fossem guiadas pela razão, mas por uma ira inconsciente, essas pessoas não se dão conta de que a violência não está somente no corpo caído, morto e ensanguentado, ou no assalto e na morte da idosa, mas começa na exclusão social, se estende ao levantamento de muros, à execução pública pelas próprias mãos. E a partir do momento em que se desfaz, por meio de uma narrativa chocante e traumática, um imaginário de quem é violento, quem é perigoso, quem é o inimigo e quem é vítima, tal narrativa causa um estranhamento, que tem a ver com "um novo enquadramento das situações. Novo justamente porque não combina com aquilo que estamos acostumados a ver, preparados para ver" ${ }^{20}$

Ao final, o narrador se prontifica a enterrar o rapaz e, ao fazê-lo, solicita que coloquem o nome dele sobre a cruz de sua cova: Miguel. $\mathrm{Na}$ tentativa de humanizar o rapaz-miserável, o único nome próprio em todo o conto é dado a alguém que, historicamente, é visto e tratado pela sociedade como "Zé Ninguém", como anônimo.

A inversão de imagem entre ofensor e ofendido também é uma estratégia narrativa no conto "El carrito", ${ }^{21}$ de Mariana Enriquez. No conto, a escritora argentina também opta por um narrador-personagem - estratégia com que se pretende conferir legitimidade ao evento narrado - para contar a história de um bairro de classe média que tem sua rotina interrompida após a passagem breve de um mendigo. Em um domingo de sol, a vizinhança se diverte nas calçadas, tomando cerveja, conversando, uns lavando

una pausa, un silencio ensordecedor. Como si aquellos hombres y mujeres hubieran recuperado finalmente la cordura, comenzaron a ceder y a echarse hacia atrás hasta dejar un vacío en el centro [...]. Con un murmullo apagado la masa fue recuperando su apariencia humana, dispersándose en grupos pequeños comenzaron a alejarse hacia sus hogares. Algunas mujeres rezagadas se tapaban los ojos o se santiguaban ante el cadáver, la mayoría apuró el paso huyendo del espanto de aquel cuerpo exánime, como si aquella ejecución pública no hubiera sido más que un terrible acontecimiento del que no habían formado parte". (SANTULLO. La zona, p. 65-67, grifos meus, tradução minha). ${ }^{20}$ DALCASTAGNÈ. Vozes nas sombras: representação e legitimidade na narrativa contemporânea, p. 91.

${ }^{21}$ As citações ligadas ao conto "El carrito" são de versão digital da obra em que não há indicação de página. 
carro, outros tomando sol, quando se aproxima um velho mendigo, negro, empurrando um carrinho de supermercado repleto de objetos retirados do lixo. Segundo a narradora, o velho - que estava bêbado e vestia uma calça velha e imunda, sem cueca por baixo - se aproximou do carro de um dos vizinhos e "cagou na calçada, merda mole, quase diarreica, e em muita quantidade; o cheiro nos chegou, fedendo tanto a merda como a álcool". ${ }^{22}$ A escolha da linguagem no conto provoca asco, aversão, e acredito que é esta a primeira sensação que a narrativa pretende incitar no leitor - a repulsa pelo mendigo negro - para, no final, subvertê-la.

Diante do acontecimento, os pais da narradora demonstram pena, compaixão em relação ao mendigo: "Pobre homem, disse minha mãe. Que miséria, a que ponto uma pessoa pode chegar, disse meu pai". ${ }^{23} \mathrm{E}$ a típica postura de uma classe média que acredita que o fato de ter pena de alguém em estado de miséria e de ajudar com uns trocadinhos - como faz a mãe da narradora no conto - já lhe garante a salvação da alma. No entanto, a "ofensa" do mendigo também desperta reações violentas e hostis. O dono da calçada, Horacio, começou a ficar nervoso e outro morador, Juancho, avança sobre o mendigo, o empurra contra o chão, fazendo-o cair sobre as próprias fezes, e começa a espancá-lo, sem dar-lhe chances de levantar, enquanto o chama de "negro de merda". Ninguém à volta impede a ação, a não ser a mãe da narradora, que sai de casa e ordena que Juancho pare. Vale destacar que o homem obedece à solicitação da mãe da narradora porque "[t]odos a respeitavam, especialmente Juancho, porque ela costumava lhe dar umas moedas para beber quando ele pedia; os outros a tratavam com deferência porque mamãe era quinesióloga, mas todos pensavam que era médica, e chamavam doutora". ${ }^{24}$ Essa informação sobre a mãe ser respeitada na vizinhança, ser reconhecida como doutora e de ser a voz boa e consciente do bairro é fundamental para a construção inicial da imagem desta personagem e da aproximação que a narrativa pretende estabelecer entre ela e o leitor. Sobre o personagem Juancho -

22 “[...] cagó en la vereda, mierda floja, casi diarreica, y mucha cantidad; el olor nos llegó, apestaba tanto a mierda como a alcohol.” (ENRIQUEZ. El carrito, tradução minha). 23 "Pobre hombre, dijo mi mamá. Qué miseria, a lo que puede llegar uno, dijo mi papá." (ENRIQUEZ. El carrito, tradução minha).

24 "Todos la respetaban, especialmente Juancho, porque ella solía darle unas monedas para vino cuando le pedía; los demás la trataban con deferencia porque mamá era kinesióloga, pero todos pensaban que era médica, y la llamaban doctora." (ENRIQUEZ. El carrito, tradução minha). 
que nem era o dono da calçada suja pelo mendigo - é possível perceber que sua atitude, embora tenha sido uma reação a um ato inadequado, é permeada por um impulso agressivo, como se estivesse fora de si:

- Aqui a doutora te perdoa, negro arrombado, mas o carro tu não vai levar. Vai pagar pela sujeira, abusado do caralho, aqui no bairro ninguém sacaneia.

Mamãe tentou dissuadir a Juancho, mas ele estava bêbado, e furioso, e gritava como um justiceiro, e em seus olhos não tinha nada branco, negro e vermelho, como as cores do short que estava vestindo. ${ }^{25}$

O mendigo se foi, e a narradora descreve a reação da vizinhança: "todos o viram ir, os galegos murmurando que barbaridade, os filhos de Coca às gargalhadas, as garotas na porta da garagem de Valeria rindo, algumas nervosas, outras cabisbaixas, como se estivessem envergonhadas". ${ }^{26}$ Até que, não satisfeito, Juancho

pegou uma garrafa do carrinho e a jogou em direção ao homem, mas passou muito longe e se espatifou contra $\mathrm{o}$ asfalto. $\mathrm{O}$ homem, assustado com o barulho, se virou e gritou algo, incompreensível. Não soubemos se falava outro idioma (mas qual?) ou se simplesmente não articulava bem por estar bêbado. Antes de sair correndo em ziguezague, fugindo de Juancho que o perseguiu aos gritos, olha para minha mãe com toda lucidez e assentiu, duas vezes. Disse algo mais, girando os olhos, abarcando toda a quadra. Depois desapareceu na esquina. ${ }^{27}$

25 “- Acá la doctora te perdona la vida, negro culeado, pero el carro no te lo llevás. La mugre la pagás, zarpado del orto, en el barrio no se jode.

Mamá intentó disuadir a Juancho, pero él estaba borracho, y furioso, y gritaba como un justiciero, y en los ojos no le quedaba nada blanco, negro y rojo, como los colores del short que llevaba puesto.” (ENRIQUEZ. El carrito, 2016, tradução minha).

26 "todos lo miraron irse, los gallegos murmurando qué barbaridad, los hijos de Coca a las risotadas, las chicas en la puerta del garaje de Valeria riéndose nerviosas algunas, otras cabizbajas, como avergonzadas." (ENRIQUEZ. El carrito, 2016, tradução minha). 27 “sacó una botella del carrito y se la revoleó al hombre, pero le pasó muy lejos y se estrelló contra el asfalto. El hombre, sobresaltado por el ruido, se dio vuelta y gritó algo, ininteligible. No supimos si hablaba otro idioma (pero ¿cuál?) o si sencillamente no podía articular por la borrachera. Pero antes de salir corriendo en zigzag, huyendo 
Após esse evento, todos os moradores do bairro passam por uma grave crise econômica: os que eram proprietários de comércios tiveram seus estabelecimentos assaltados; os que tinham dinheiro em conta tiveram todo o valor sacado; perderam emprego; começaram a vender bens por preço bem abaixo do valor; não conseguiam mais pagar contas, comprar comida ou ter acesso a serviços básicos. Todos no bairro entraram em situação de miséria extrema, a ponto de começarem a comer seus animais de estimação. Exceto a família da narradora, que ainda tinha dinheiro, comida, luz, água e até internet, situação que escondiam da vizinhança por medo de uma reação violenta. Entendo esse medo como um reflexo da imagem que foi construída de pessoas em situação de miséria: uma reação violenta. $\mathrm{O}$ conto de Enriquez mostra para o leitor alguns dos maiores medos da classe média: tornar-se pobre e ser alvo de violência dos pobres. Diante disso, a família decide se reunir para resolver o que fazer, ir embora do bairro ou continuar vivendo com fartura e conforto de forma clandestina.

Juancho acreditava que tudo isso estava acontecendo por culpa do mendigo: "É o carrinho de merda, o carrinho do velho mendigo... é o carrinho, é culpa do velho [...], nos fez uma macumba", ${ }^{28}$ tese com a qual passam a concordar a narradora e o irmão:

Perguntei-lhe se achava que Juancho tinha razão. Disse que sim com a cabeça.

- Mamãe nos salvou. Viu como o homem olhou para ela, antes de ir? Nos salvou.

- Por enquanto - disse eu.

- Por enquanto - disse ele. ${ }^{29}$

O final do conto dá indícios de um final trágico e cruel para o mendigo negro, cometido por alguém da vizinhança. A mãe, "doutora",

de Juancho que lo persiguió a los gritos, miró a mi mamá con toda lucidez y asintió, dos veces. Dijo algo más, girando los ojos, abarcando toda la cuadra y más. Después desapareció por la esquina." (ENRIQUEZ. El carrito, 2016, tradução minha).

28 "Es el carrito de mierda, el carrito del villero... es el carrito, es culpa del viejo [...], nos hizo una macumba." (ENRIQUEZ. El carrito, 2016, tradução minha).

29 "Le pregunté si pensaba que Juancho tenía razón. Dijo que sí con la cabeza.

- Mamá nos salvó. ¿Viste cómo la miró el hombre, antes de irse? Nos salvó.

- Hasta ahora - dije yo.

- Hasta ahora - dijo él.” (ENRIQUEZ. El carrito, 2016, tradução minha). 
respeitada no bairro e no lar e a grande salvadora da família, mesmo parecendo saber do ocorrido, não faz nada para impedir:

Essa noite, sentimos cheiro de carne queimada. Mamãe estava na cozinha; nos aproximamos para impedi-la, tinha ficado louca, fazer um bife na grelha a essa hora, iam desconfiar. Mas mamãe tremia ao lado do balcão.

- Essa não é uma carne comum - disse.

Abrimos apenas a persiana e olhamos para cima. Vimos que a fumaça vinha do terraço da frente. E era negra, e não cheirava parecido a nenhuma outra fumaça.

- Que velho mendigo filho da puta - disse mamãe, e se pôs a chorar. ${ }^{30}$

Se constantemente as narrativas que diziam retratar a realidade das periferias e de desigualdades sociais relacionavam atos de crueldade e de violência grotesca a grupos marginais, Mariana Enriquez transfere tais ações a personagens socioeconomicamente privilegiadas, desconcertando o leitor com um final não familiar. O horror recai sobre a vizinhança de classe média e da mãe, dos quais o leitor possivelmente se afastará afetivamente após a leitura do conto. A vítima passa a ser o mendigo negro, cujas ações, embora tenham sido inadequadas, não sem comparam em vileza às de Juancho, às da vizinhança ou à omissão da mãe da narradora. Dessa forma, a narrativa, por meio do choque do real, confronta o discurso e a visão sobre o indivíduo marginal que prevalecia até recentemente. A ideia de veracidade é reforçada pelo fato de a voz narrativa, em primeira pessoa, ser da própria representante da família, filha da "doutora", ou seja, não foi alguém de fora que observou e narrou, mas alguém pertencente a este grupo e que viveu toda a história.

A narrativa em primeira pessoa também dá voz a um jovem negro no conto "Fábrica de fazer vilão", de Ferréz. Pelo ponto de vista do

\footnotetext{
30 "Esa noche, olimos carne quemada. Mamá estaba en la cocina; nos acercamos para retarla, se había vuelto loca, hacer un bife a la parrilla a esa hora, se iban a dar cuenta. Pero mamá temblaba al lado de la mesada.

- Esa no es carne común - dijo.

Abrimos apenas la persiana y, miramos para arriba. Vimos que el humo llegaba de la terraza de enfrente. Y era negro, y no olía como ningún otro humo conocido.

- Qué viejo villero hijo de puta - dijo mamá, y se puso a llorar." (ENRIQUEZ. El carrito, 2016, tradução minha).
} 
narrador-personagem nos deparamos com a postura racista dos policiais. O rapaz é rapper e, nos momentos em que não ajuda a mãe, compõe raps na esperança de um dia gravar um disco.

O conto tem início com a descrição de partes do cotidiano do narrador: "Cobertor fino, parece lençol, mas um dia melhora. Os ruídos dos sons às vezes incomodam, mas na maioria ajudam. Pelo menos sei que tem um monte de barraco cheio, monte de gente vivendo". ${ }^{31}$ Em seguida, dois policiais chegam ao bar administrado pela mãe do rapaz. Embora não haja sangue ou a morte anunciada pelo agente da lei, a narrativa revela a violência e o racismo diários que sofrem negros da favela:

É o seguinte, por que esse bar só tem preto? [pergunta o policial]

Ninguém responde, vou ficar calado também, não sei por que somos pretos, não escolhi.

Vamos, porra, vamos falando, por que aqui só tem preto?

Por que o que, macaca?

Minha mãe num é macaca.

Cala a boca, macaco, eu falo nesse caralho. [...]

Fala, macaca.

É que todo mundo na rua é preto.

Ah! Ouviu essa, cabo, todo mundo na rua é preto.

Por isso que essa rua só tem vagabundo [...]. ${ }^{32}$

Vemos na fala do policial a associação do negro à "vagabundagem", à criminalização. Esta relação é feita a partir de um discurso do policial que nos é apresentado pelo narrador. Não é alguém distanciado que observa o fato e narra, mas o próprio ofendido, o que confere autenticidade ao acontecimento narrado.

Temos o ponto de vista não só pelo fato de o jovem negro ser o narrador, mas a maneira como a narrativa é conduzida direciona nosso olhar como se fosse o dele. Em um momento em que revela ter vontade de responder ao policial, o jovem diz se segurar por temer ser baleado; seu olhar para a arma também é o nosso: "Penso em falar, sou do rap, sou guerreiro, mas não paro de olhar a pistola na mão dele". ${ }^{33}$

\footnotetext{
${ }^{31}$ FERRÉZ. Fábrica de fazer vilão, p. 11.

${ }^{32}$ FERRÉZ. Fábrica de fazer vilão, p. 12-13.

${ }^{33}$ FERRÉZ. Fábrica de fazer vilão, p. 12-13.
} 
Outra estratégia narrativa foi colocar na fala do policial a visão estereotipada do senso comum sobre as intenções e os objetivos que tem o negro pobre e favelado: "Mas se eles te pegam na rua, comem sua mulher, roubam seus filhos sem dó". ${ }^{34}$ A narrativa não mostra o personagem negro e pobre cobiçando a mulher de outrem ou roubando pessoas na rua. Dessa forma, o conto reforçaria um estereótipo que, de tão recorrente em filmes e histórias, acredita-se ser a realidade. Quando este imaginário está na fala de alguém que no contexto da história se revela como cruel, violento e racista, passamos a questionar tal estereótipo, uma vez que quem o reproduz não tem crédito moral.

Esta divergência na narrativa é, segundo Regina Dalcastagnè, o que diferencia um modo de representação exótico de um modo crítico. A ideia de que o negro pobre marginalizado só está atrás do dinheiro, do estilo de vida e das mulheres das famílias de classe média é recorrente nas narrativas realistas, mas o que caracteriza uma como estereotipada e outra como desconstrutora é o fato de este imaginário estar ou não de acordo com os valores do narrador. ${ }^{35}$ Nesse sentido, a estereotipação seria uma retratação familiarizada com o senso comum, segundo Jaguaribe, ou o que Flusser chama de nível agradável da experiência.

Por isso, os contos de Laura Santullo e Mariana Enriquez seriam exemplo do belo de Flusser, pois não estereotipam, uma vez que, mesmo o narrador-personagem sendo de classe média, não compartilha do senso comum sobre o pobre marginalizado. Assim como o conto de Ferréz humaniza o negro e o pobre dando-lhe voz, e uma voz que quando discursa e fala de si e de suas experiências se distancia de todo o imaginário negativo histórico e culturalmente construído.

Outro exemplo de narrativa que "desfaz o empacotamento costumeiro"36 é o conto de Marcelino Freire, "Vestido Longo". Narrado também em primeira pessoa, conhecemos a história de uma prostituta, contada por ela mesma. Negra, nordestina e muito pobre, a narradorapersonagem comenta que nunca pôde se vestir, porque não tinha roupa:

Nunca, nunquinha que eu vesti um vestido longo. Sempre nuazinha, quando pequenininha, com a tabaquinha de fora.

${ }^{34}$ FERRÉZ. Fábrica de fazer vilão, p. 12-13.

${ }^{35}$ DALCASTAGNÈ. Vozes nas sombras: representação e legitimidade na narrativa contemporânea, p. 86.

${ }^{36}$ JAGUARIBE. O choque do real: estética, mídia e cultura, p. 122. 
A barriguinha. Mamãe não tinha o que comer. E a gente ficava ali, agarrada à sainha curta dela, na costela, feito sarna, piolho, sebo, carrapato. Eu não tinha nem sapato. $O$ pé no pé, na sola da calçada. Uma miséria braba. Uma miséria pornográfica, é. Por-no-grá-fi-ca.

A miséria no Brasil, puta que pariu, é pornográfica. De nascença. Todo mundo nu. Assim que nasce, aparece, cresce, exibindo a bunda [...].

Quem podia tinha. Zorbinha, tanguinha florida. Eu, até os nove, vivia enroladinha. Na lama, na curva da rua, na sombra. Um paninho que minha mãe costurava apenas para esconder a flor. Para eu não ser abusada por nenhum agricultor. $^{37}$

$\mathrm{O}$ fato de ter tido sempre o corpo à mostra não foi porque a moça queria chamar a atenção, mas por não ter condições de se "tapar" por completo. A menina foi crescendo e atraindo olhares dos homens, que se aproveitam da inocência e da sua necessidade para abusar dela. Ainda quando criança, o dono de uma farmácia lhe pediu que o ajudasse a "limpar o estabelecimento". Em troca, ganharia um pirulito, uma moeda. A menina vai, e tem início sua desgraça. O abuso a traumatiza. Só depois de crescida a personagem tem noção do que acontecia com ela, sua inocência a impossibilitava de enxergar a gravidade da situação por que passava. Depois do primeiro abuso, outros o sucederam. Em uma sociedade machista, não há para onde correr: o homem acredita ser dono do corpo da mulher, estando vestida ou não. E se a mulher realmente não está "coberta", é considerada despudorada e fácil. E quando "cai" na mão de um, acreditam ter o direito de a possuírem todos também, afinal, ela já é "da vida". Assim a trajetória da narradora-personagem. $\mathrm{O}$ choque do real é construído com uma linguagem não explícita, mas carregada de dor e violência:

O velho da farmácia gostava de se esfregar em mim. Menininha, venha aqui. Não quer fazer uma faxina? E tirava a vassoura e pedia para eu levantar aquela vassoura. E escovava o meu corpo. E limpava lá dentro, o meu corpo de anjo. Sim, de anjo. O marmanjo babava, caduco. E depois me dava uma moeda, um cascudo. E eu devia ser

${ }^{37}$ FREIRE. Vestido longo, p. 25. 
boa de faxina. Porque veio mais gente chegando. Passando o rodo. Um monte de cachorro, abusando do meu jeito. Pelado. Do meu jeito de mexer. Inocente. Achando que o mundo respeita quando a boneca está descabelada. Respeita quando a boneca está quebrada. Respeita quando a boneca está esfolada. E eu gostava de saber o que tinha dentro da boneca. O que tem, mãe, no coração da boneca? Nadinha, minha filha, nada. ${ }^{38}$

Um dia, a mãe da narradora morre. Os irmãos vão para o campo de carvão. Ela, para um convento, onde é excomungada. A moça foge e vai parar na casa de Dona Kalil, que finalmente a veste. De minissaia. É então ensinada a agradar e a obedecer aos homens que frequentam a casa. Seu corpo torna-se produto assíduo de um gringo. E, embora tenha conseguido dinheiro além do necessário para o sustento, a agora mulher reclama do fato de, mesmo no momento em que finalmente tem dinheiro, estar cada vez mais nua: "Um gringo me falou: o legal do país de vocês é a sensualidade. [...] E o gringo me trazia colar. Anel, corrente. O gringo me encheu de tudo. Menos de roupa. Cada vez mais nua, porra. Cada vez mais pelada." 39

Agora que tem dinheiro, a narradora-personagem vê um vestido longo. Nunca tivera um. Nunca vestira um. Ela não se importa com o custo, apenas o quer. E o compra pensando na mãe, que ficaria feliz em vê-la em um vestido longo e chique, cobrindo tudo o que não pôde cobrir a vida inteira:

Tenho dinheiro, posso gastar. Juntei para comprar. O meu primeiro vestido. Pena que minha mãe já está no céu, coberta de nuvens. E não verá. A sua florzinha, como vai ficar um luxo. Juro. Será o meu primeiro vestido este. O primeiro vestido longo a gente nunca esquece. Lá na rua vai ser a novidade. Olha só aquela puta, parece uma dama. De honra. Sim, com muita honra. Na esquina, tão diferente das outras meninas da esquina. Uma nova realidade. Eu vou mostrar. ${ }^{40}$

\footnotetext{
${ }^{38}$ FREIRE. Vestido longo, p. 25-26.

${ }^{39}$ FREIRE. Vestido longo, p. 29-30.

${ }^{40}$ FREIRE. Vestido longo, p. 30, grifos meus.
} 
O fragmento acima revela outra intenção por trás do desejo de possuir um objeto caro: não é questão de conferir um status por meio da vestimenta, mas sim de tentar compensar toda uma experiência de trauma causada pela pobreza. A miséria impactava na nudez, e o fato de ter tido o corpo sempre exposto causou tragédias e feridas físicas e emocionais na personagem. É tentar suprir o fato de nunca ter podido se vestir e todas as consequências que isto acarretou. Freire, por meio de uma linguagem objetiva sem ser explícito, choca o leitor com uma realidade nova - "Uma nova realidade. Eu vou mostrar" - com a qual não estamos acostumados: ele humaniza uma prostituta e desperta empatia por ela. Ocorre a desfamiliarização de que fala Jaguaribe, ao desconstruir todo o imaginário que há na sociedade sobre a "vida fácil", pois percebemos que de fácil não tem nada. Isso acontece não só por conhecermos a história pelo ponto de vista da protagonista, mas pela maneira como a narrativa é conduzida e pela linguagem utilizada.

Contos como o de Santullo, Enriquez, Ferréz e Freire seguem o que Karl Erik Schollhammer definiu como contemporâneo: captam seu tempo e o enxergam. ${ }^{41} \mathrm{E}$ acrescento aqui: nos fazem enxergá-lo. Além disso, são obras que possuem a vontade ou o projeto de retratar a realidade na dureza com a qual é composta - e não uma ilusão de realidade do realismo tradicional -, buscando o efeito de real de outros modos. ${ }^{42}$ Algumas das estratégias são a mudança de ponto de vista e a provocação do efeito de real por meio de um "aspecto performático e transformador da linguagem e da expressão artística, privilegiando o efeito afetivo e sensível em detrimento da questão representativa." ${ }^{43} \mathrm{Em}$ outras palavras, estratégias narrativas e linguísticas que nos aproximam da realidade atual por meio de uma experiência estética - construída por uma nova linguagem literária - e nos envolvem afetivamente, suscitando sensações, novos modelos de vivência e outras experiências do cotidiano.

O que Schollhammer, Dalcastagnè, Pellegrini e Candido apontam como característica principal da narrativa contemporânea pode ser compreendida como a proposição sobre o Belo de Flusser. Uma vez que o belo está relacionado a uma experiência que confronta o senso comum culturalmente entranhado para revelar novas informações. São narrativas

\footnotetext{
${ }^{41}$ SCHOLLHAMMER. Ficção brasileira contemporânea, p. 9-10.

${ }^{42}$ SCHOLLHAMMER. Ficção brasileira contemporânea, p. 53-54.

${ }^{43}$ SCHOLLHAMMER. Ficção brasileira contemporânea, p. 57.
} 
que chocam e incomodam porque contrariam nossa experiência de nível "agradável", ou seja, os modelos de vivência com os quais estamos acostumados.

A estética do choque do real, característica do novo realismo, é um caminho para se chegar ao belo porque nos permite olhar de frente essa realidade, uma vez que é por meio do choque que a narrativa - na medida em que propicia uma aproximação das experiências e vivências narradas - desloca o leitor de uma postura contemplativa e confortável para uma postura mais incômoda, porém (ou por isso) mais humana e empática.

\section{Referências}

CANDIDO, Antonio. A nova narrativa. In: . A educação pela noite e outros ensaios. São Paulo: Ática, 1989. Disponível em: http:// paginapessoal.utfpr.edu.br/mhlima/Antonio_Candido-_A_educacao_ pela_noite_e_outr-BookFi.org.pdf. Acesso em: 25 ago. $\overline{201} \overline{9}$.

CANDIDO, Antonio. Vários escritos. 5. ed. Rio de Janeiro: Ouro Sobre Azul, 2011.

DALCASTAGNÈ, Regina. Vozes nas sombras: representação e legitimidade na narrativa contemporânea. In: (org.). Ver e imaginar o outro: alteridade, desigualdade, violência na literatura brasileira contemporânea. São Paulo: Editora Horizonte, 2008. p. 78-107.

ENRIQUEZ, Mariana. El carrito. In: la cama. Bogotá: Laguna Libros, 2016. Versão digital.

FERRÉZ. Fábrica de fazer vilão. In: Paulo. Rio de Janeiro: Objetiva. 2006. p. 11-14.

FLUSSER, Vilém. A arte: o belo e o agradável. Tradução de Rachel Cecília de Oliveira Costa. Artefilosofia, Ouro Preto, n. 11 p. 9-13, dez. 2011. Disponível em: http://www.periodicos.ufop.br/pp/index.php/raf/ article/view/593/549. Acesso em: 13 jan. 2019.

FLUSSER, Vilém. Comunicologia: reflexões sobre o futuro. Tradução de Tereza Maria Souza de Castro. São Paulo: Martins Fontes, 2014.

FREIRE, Marcelino. Vestido longo. In: . Amar é crime. 2. ed. Rio de Janeiro: Record, 2015. p. 25-32. 
JAGUARIBE, Beatriz. O choque do real: estética, mídia e cultura. Rio de Janeiro: Rocco, 2007.

PELLEGRINI, Tânia. No fio da navalha: literatura e violência no Brasil de hoje. In: DALCASTAGNÈ, Regina (org.). Ver e imaginar o outro: alteridade, desigualdade, violência na literatura brasileira contemporânea. São Paulo: Editora Horizonte, 2008. p. 41- 56.

SANTULLO, Laura. La zona. In: . El otro lado. Montevideo: Ediciones de la Banda Oriental, 2005. p. 55-68.

SCHOLLHAMMER, Karl Erik. Ficção brasileira contemporânea. 2. ed. Rio de Janeiro: Civilização Brasileira, 2011. 